\title{
THE RELATIONS AMONG MOTIVATION, THE AMOUNT OF OUT-OF-CLASS READING, AND ACHIEVEMENT IN FOREIGN LANGUAGE READING. ${ }^{1}$
}

\author{
LAS RELACIONES ENTRE LA MOTIVACIÓN, LA CANTIDAD \\ DE LECTURAS EXTRAESCOLARES Y LOS LOGROS EN LECTURA \\ EN IDIOMAS EXTRANJEROS
}

\author{
FEIFEI HAN \\ Griffith University, Australia \\ feifei.han@griffith.edu.au
}

\begin{abstract}
This paper reports the results of a study on the relations among motivation, the amount of out-of-class reading, and achievement in foreign language reading among 322 English language learners in the Chinese tertiary setting. Motivation in English reading was measured by five scales representing intrinsic and extrinsic motivation components. The amount of out-of-class English reading consisted of academic and non-academic English reading. Achievement in English reading was tested by a reading section of a practice College English Test Band-4. The results showed that intrinsic motivation comprised of involvement and avoidance, and extrinsic motivation comprised of utility value, academic value, and recognition value. The path analysis, which examined the extent to which motivation and the amount of reading contributed to achievement in English reading, revealed that the amount of academic English reading was the only significant direct predictor to achievement in English reading, but intrinsic motivation indirectly contributed to achievement in English reading with the amount of academic English reading being a mediator.
\end{abstract}

Keywords: Motivation in FL reading; amount of out-of-class reading; achievement in reading; English language learners; mediator.

\section{RESUMEN}

Este documento informa sobre un estudio sobre las relaciones entre la motivación, la cantidad de lecturas extraescolares y los logros en lectura en idiomas extranjeros entre 322

${ }^{1}$ This article is circumscribed in the project "The impact of psychological factors on English reading practice and outcomes among English language learners in Chinese tertiary setting" from the Griffith University. 
estudiantes de inglés en un entorno terciario chino. La motivación en la lectura en inglés se midió mediante cinco escalas que representan componentes de motivación intrínseca y extrínseca. La cantidad de lecturas de inglés fuera de la clase consistió en lecturas académicas y no académicas de inglés. El logro en lectura en inglés fue probado por una sección de lectura de una práctica College English Test Band-4. Los resultados mostraron que la motivación intrínseca comprendía la participación y la evitación, y la motivación extrínseca comprendía el valor de utilidad, el valor académico y el valor de reconocimiento. El análisis de la trayectoria, que examinó hasta qué punto la motivación y la cantidad de lectura contribuyeron al logro en la lectura en inglés, reveló que la cantidad de lectura académica en inglés fue el único factor predictivo directo significativo para el logro en la lectura en inglés. Sin embargo, la motivación intrínseca contribuyó indirectamente al logro en inglés con la cantidad de lectura académica en inglés como mediador.

Palabras clave: Motivación en la lectura de FL; cantidad de lecturas fuera de clase; logro en la lectura; los estudiantes del idioma inglés; mediador.

Recibido: 30/03/2019. Aceptado: 10/06/2019.

\section{INTRODUCTION}

$\mathrm{R}$ eading in first language (L1) is an effortful activity, it becomes extremely cognitive demanding in foreign language (FL) reading (Grabe and Stoller, 2013). In the process of FL reading practice, motivation becomes highly important because it may affect how much effort a learner is willing to put in the process and how sustainable such effort is. For English language learners (ELLs) in China, their English learning largely occurs in classroom settings and English is hardly used in their daily life. In a typical English class in China, English teachers often devote a large amount of time to vocabulary and grammar instruction in a detailed manner to help learners acquire new words and difficult syntactic structures. Reading in English predominantly serves as an essential channel for linguistic input rather than honing students' English reading skills (Han, 2012). Due to limited class time, this may require Chinese ELLs to pratice English reading outside their normal English classes. Is the amount of out-of-class reading in English related to Chinese ELLs' motivation in English reading? Are the relations the same or different for the out-of-class practice of academic English reading and non-academic English reading? To what extent does motivation in English reading and the amount of out-of-class English reading contribute to achievement in English reading? These are the questions addressed in the current study. In the following part, the existing studies on motivation, the amount of reading, and achievement in L1 and FL reading are reviewed. 


\section{LITERATURE REVIEW}

\subsection{Motivation, the Amount of Reading, and Achievement in L1 Reading}

Guthrie and Wigfield (2000) maintain that motivation in reading is a domainspecific construct, which involves beliefs, goals, and values in the processes of reading. Wigfield (1997a) believes that motivation in reading is distinguished from motivation in general academic learning. In the past three decades, motivation in $\mathrm{L} 1$ reading has been widely researched among children. These studies have demonstrated that motivation in L1 reading is multidimensional and consists of related but distinct components.

In an early attempt to measure English-speaking children's motivation in L1 reading, Wigfield and Guthrie (1997) constructed the Motivation for Reading Questionnaire (MRQ) drawing multiple theories from intrinsic and extrinsic motivation, self-efficacy, expectancy-value, and achievement goals. The MRQ encompassed 11 scales forming four dimensions of motivation in L1 reading. These dimensions and scales were self-efficacy (i.e., reading efficacy and challenge); intrinsic motivation (i.e., curiosity, involvement, importance of reading, and avoidance of reading); extrinsic motivation (i.e., competition, recognition for reading, and reading for grades); and social motivation (i.e., social reasons for reading and compliance). To expand the investigation of the structure of motivation in L1 reading, Wang and Guthrie (2004) conducted a study with children in US and in China to investigate their English reading motivation and Chinese reading motivation respectively using the Revised MRQ (MRQ-R). Consistent across the two cohorts of children, the study showed that motivation in L1 reading consisted of eight scales representing two broad dimensions: curiosity, involvement, and preference for challenge scales represented intrinsic dimension for reading; whereas recognition, grades, social reasons, competition, and compliance scales formed extrinsic dimension for reading.

With adult populations, research has also identified that motivation in L1 reading consisted of an intrinsic and an extrinsic dimension, though the two dimensions were formed by different factors. For instance, Schutte and Malouff (2007) reported that intrinsic motivation consisted of reading as part of the self and reading efficacy; and extrinsic motivation comprised of reading for recognition and reading to do well in other realms.

A handful of studies have explored the relation between motivation and the amount of L1 reading among both child population (e.g., Guthrie, Wigfield, Metsala, and Cox, 1999; Wang and Guthrie, 2004; Wigfield and Guthrie, 1997) and adult population. However, this area of research generated inconsistent results. Some studies found that both intrinsic and extrinsic motivation had positive association with the amount of reading outside schools (e.g., Guthrie et al., 1999; 
Wigfield and Guthrie, 1997), with the intrinsic dimension having stronger association than the extrinsic dimension. Other research reported that only intrinsic motivation had significant correlation with the amount of reading (e.g., Wang and Guthrie, 2004).

The relation between motivation and achievement in $\mathrm{L} 1$ reading have also been investigated among both children (e.g., Gottfried, 1990; Guthrie et al., 1999; Lau and Chan, 2003; Law, 2009; Wigfield et al., 2004) and adults (e.g., Schutte and Malouff, 2007; Vansteenkiste, Simons, Lens, Sheldon and Deci, 2004). The general finding of this line of research demonstrated positive association between intrinsic motivation and achievement in reading. For instance, among American students in primary school, Guthrie et al. (2007) found that the two components of intrinsic motivation - involvement and efficacy - were positively associated with students' reading comprehension scores.

The relation between extrinsic motivation and achievement in L1 reading appeared to be inconsistent. Among primary school students, Wang and Guthrie (2004) found a negative relation between Chinese and American students' extrinsic motivation and their achievement in Chinese reading and English reading respectively. With secondary school students, Mucherah and Yoder (2008) found that the two scales of extrinsic motivation (grades and competition) did not relate to students' reading comprehension. Similarly, among Belgian high school students, students with higher and lower extrinsic orientations did not differ on their reading proficiency scores (Vansteenkiste et al., 2004). Lau and Chan (2003) examined Chinese students' extrinsic motivation and Chinese reading achievement and found a positive relation between extrinsic motivation and achievement. Such results showed divergence from the Mucherah and Yoder's and Vansteenkiste et al.'s studies conducted with students in Western countries. The different relational patterns between extrinsic motivation and achievement in L1 reading indicate that the relation might be affected by the learning context.

The interrelations between motivation, the amount of reading, and achievement in L1 reading are even more complex. Schaffner, Schiefele, and Ulferts (2013) used Structural Equation Modeling (SEM) to examine whether the amount of reading mediated between the prediction from intrinsic and extrinsic motivation to reading comprehension among grade 5 students. The results of SEM indicated that while the amount of reading mediated the positive effect from intrinsic motivation to reading comprehension, extrinsic motivation exerted both indirect and direct negative effects on reading comprehension.

\subsection{Motivation, the Amount of Reading, and Achievement in FL Reading}

Research on motivation in FL reading has largely been based on research in mo- 
tivation in L1 reading. Using MRQ developed by Wigfield and Guthrie (1997), and incorporating Gardner's (2001) integrative motivation theory, Mori (2002) found four factors of motivation in FL reading among Japanese ELLs. The four factors were intrinsic value of reading, extrinsic utility value of reading, importance of reading, and reading efficacy.

Researchers have also examined the relation between motivation in L1 and FL reading. Lin, Wong, and McBride-Chang (2012) used paralleled questionnaires to measure Hong Kong $5^{\text {th }}$ graders' motivation in Chinese reading (L1) and English reading (FL). Confirmatory factor analyses (CFAs) retained eight paralleled factors for both motivation in L1 and FL reading. Among the eight factors, four of them were intrinsic motivation, including self-efficacy, curiosity, involvement, and recreation; two of them were extrinsic motivation, including grade and instrumentalism scales; and the other two were social motivation, namely social-family and social-peer scales. Altogether the eight components could explain approximately $12 \%$ variance in achievement in English reading.

Among Korean university ELLs, Kim (2011) also investigated how motivation in L1 reading and in FL reading are related. Using Exploratory Factor Analyses (EFAs), Kim retained four scales for both motivation in L1 reading (i.e., intrinsic motivation for $L 1$ reading, avoidance of $L 1$ reading, utility value of $L 1$ reading, and information-related motivation for $L 1$ reading) and in FL (i.e., intrinsic motivation for $F L$ reading, avoidance of $F L$ reading, utility value of FL reading, and learning-goal oriented motivation in FL reading). Furthermore, Kim also found that students' academic majors affected the relation between motivation and achievement in FL reading. For non-English majors, intrinsic motivation for FL reading and avoidance of FL reading significantly related to English reading proficiency: students who obtained higher scores in English reading felt more intrinsically motivated and were less likely to avoid reading difficult English texts; whereas lower-achieving students had lower intrinsic motivation and tended to avoid English reading more frequently. This pattern however was not replicated among students with English major.

There is a dearth of research on the relation between reading motivation and the amount of out-of-class reading in FL. One of exceptions was Takase (2007), in which the number of English books read in a semester-long extensive English reading course for Japanese students was recorded. Students' Japanese (L1) and English (FL) reading motivation was measured using a questionnaire. Takase reported that the levels of intrinsic motivation in Japanese reading and extrinsic motivation in English reading predicted how many English books read by students in the extensive reading course for the whole semester. Moreover, he found that while the amount of English reading was significantly related to Japanese ELLs' English reading proficiency, none of the motivation scales in L1 and in FL reading was related to with English reading proficiency. The setting of the study was 
an English extensive course, which is difficult for the findings to be generalized to other FL learning contexts where no such course is available. For most Chinese ELLs at university level, their English classes are often used for vocabulary and grammar instruction, and do not give them time to practice English reading. Thus, it is important and more meaningful to investigate the relations between motivation in English reading, the amount of out-of-class English reading, and English reading achievement. Furthermore, Takase's study did not examine if the amount of out-of-class English reading serves as a mediator between motivation and achievement in FL reading as in L1 reading research (e.g., Schaffner et al., 2013). The current study will attempt to fill the gap by using Chinese ELLs at the tertiary level as a sample.

\section{RESEARCH OVERVIEW AND QUESTIONS}

The current study aimed to examine the relations among motivation in English reading and the amount of out-of-class English reading, and English reading achievement; and the extent to which motivation in English reading and the amount of out-of-class English reading contribute to English reading achievement among Chinese ELLs at the tertiary level. Two types of the amount of out-of-class English reading were investigated: the amount of academic English reading, and the amount of non-academic English reading. The current study addressed the following three research questions:

(1) What are the relations among motivation in English reading, the amount of out-of-class English reading, and English reading achievement among university students?

(2) What are the relations between motivation in English reading, the amount of out-of-class English reading, and English reading achievement at the level of variables?

(3) To what extent do motivation in English reading and the amount of out-ofclass English reading contribute directly to English reading achievement? Does the amount of out-of-class English reading mediate the prediction from motivation in English reading to English reading achievement?

\section{METHOD}

\subsection{Sampling}

The study was conducted in two Chinese public universities with 322 sopho- 
mores. Among them, 183 were from one university and were enrolled in an engineering degree, and the rest of 139 were from another university and were enrolled in a business degree. On average, the participants' age was 20 years old, ranging between 18 and 23. The participants all received compulsory English language instruction for seven years, with six years in the secondary school, and one year in the university.

\subsection{Data Collection Tools and Procedure}

Students' motivation in English reading was measured using Motivation in English Reading Questionnaire, and the amount of out-of-class English reading was measured by Amount of Out-of-class English Reading Questionnaire. The participants' achievement in English reading was assessed using a practice College English Test Band 4 (CET-4). In the following section, the details of the three instruments are described.

\subsubsection{Motivation in English Reading Questionnaire (MERQ)}

The MERQ was designed based on the literature in motivation in L1 and FL reading. As mentioned in the literature review, in motivation in L1 reading research, the MRQ and MRQ-R have been constructed (Baker and Wigfield, 1999; Wang and Guthrie, 2004; Wigfield, 1997b) to examine motivation in L1 reading among children. As a result, some items are not suitable for the participants, who were adult ELLs. For example, both the MRQ and MRQ-R involved items regarding motivation in reading inspired by siblings, which appeared not to be applicable due to "one child policy" in China. Therefore, these items were not selected in the design of the MERQ. In compiling the questionnaire, research on motivation in FL reading, which were mostly conducted with adolescent and adult ELLs in Japan and Korea, was also consulted (e.g., Kim, 2011; Mori, 2002; Mori, 2004; Takase, 2007). The questionnaires used in these studies were also largely based on the MRQ and MRQ-R.

The MERQ had 24 items, which encompassed two scales: intrinsic motivation in English reading and extrinsic motivation in English reading, each of which comprised of sub-scales. Intrinsic motivation scale consisted of two sub-scales: (1) involvement in English reading ( 7 items, $\alpha=.86$, eigen value = 1.82), and (2) English reading avoidance ( 4 items, $\alpha=.86$, eigen value $=1.37$ ); whereas extrinsic motivation scales comprised of three sub-scales: (3) utility value of English reading (4 items, $\alpha=.71$, eigen value $=6.60$ ), (4) academic value of English reading ( 4 items, $\alpha=.74$, eigen value $=1.82$ ), and (5) recognition value of English reading ( 5 items, $\alpha=.74$, eigen value $=1.16$ ). All the sub-scales had reliability of more than .70 . 
The anchors of the questionnaire were 1 to 5 , with 1 and 5 representing "strongly disagree" and "strongly agree" respectively. The item descriptions and factor loadings of the items on their respective scales are presented in Table 1.

Table I. Factor loadings and reliability of the MERQ

\begin{tabular}{|c|c|c|}
\hline Scale & Items & Rotated Factor Loadings \\
\hline \multirow{4}{*}{$\begin{array}{l}\text { involvement } \\
\text { of English } \\
\text { reading }\end{array}$} & I am good at reading in English. & .79 \\
\hline & $\begin{array}{l}\text { I like reading English novels, } \\
\text { newspapers, and/or magazines. }\end{array}$ & .53 \\
\hline & $\begin{array}{l}\text { I tend to get deeply engaged when } \\
\text { I read in English. }\end{array}$ & .55 \\
\hline & $\begin{array}{l}\text { It is easy for me to get the meaning } \\
\text { of the sentences in English read- } \\
\text { ing. }\end{array}$ & .75 \\
\hline \multirow{4}{*}{$\begin{array}{l}\text { avoidance of } \\
\text { English read- } \\
\text { ing }\end{array}$} & $\begin{array}{l}\text { It is a waste of time to learn to read } \\
\text { in English. }\end{array}$ & .65 \\
\hline & $\begin{array}{l}\text { I do not have any desire to read in } \\
\text { English even if the content is in- } \\
\text { teresting. }\end{array}$ & .60 \\
\hline & $\begin{array}{l}\text { I usually try to finish English read- } \\
\text { ing assignments on time. (reversed } \\
\text { wording) }\end{array}$ & .54 \\
\hline & $\begin{array}{l}\text { I would not voluntarily read in } \\
\text { English unless it is required as } \\
\text { homework. }\end{array}$ & .68 \\
\hline \multirow[t]{3}{*}{$\begin{array}{l}\text { utility value } \\
\text { of English } \\
\text { reading }\end{array}$} & $\begin{array}{l}\text { English reading is important be- } \\
\text { cause it enables me to read English } \\
\text { novels, newspapers, and/or maga- } \\
\text { zines. }\end{array}$ & .64 \\
\hline & $\begin{array}{l}\text { English reading is important in } \\
\text { that we need to cope with global- } \\
\text { ization. }\end{array}$ & .58 \\
\hline & $\begin{array}{l}\text { English reading is important be- } \\
\text { cause it can help me search and } \\
\text { read information on the Internet. }\end{array}$ & .66 \\
\hline
\end{tabular}


English reading is important be.73 cause it makes me a more knowledgeable person.

English reading is important be-

cause it helps me to learn about various opinions' in the world.

English reading is important because it broadens my view.

English reading is important because it helps me to understand more deeply about lifestyles and cultures of English speaking countries.

\begin{tabular}{lll}
\hline $\begin{array}{l}\text { academic } \\
\text { value of Eng- }\end{array}$ & .72 \\
lish reading & CET Bead English to succeed in Eng- \\
& When some classmates read Eng- \\
& lish better than me, I want to read \\
& more English materials. \\
& I read in English to become a faster \\
& reader. \\
& I read in English in order to en- \\
& large my English vocabulary. & .44 \\
\hline I read English to excel in English \\
recognition \\
value of Eng- \\
lish reading & I feel happy when someone recog- \\
& nizes my English reading ability. \\
& I like hearing the teacher or (and) \\
& classmates say I am good at Eng- \\
& lish reading. \\
& I feel happy when my classmates \\
& ask me for help with their English \\
& reading tasks. \\
& It is important for me to perform \\
& better in English reading than oth- \\
& er classmates.
\end{tabular}

Notes: $\mathrm{KMO}=.88$ 


\subsubsection{Amount of Out-of-class English Reading Questionnaire (AOERQ)}

The AOERQ was designed with six items assessing three most common academic and non-academic out-of-class English reading practice respectively. The construction of the items came from Chinese university students' and English teachers' responses of out-of-class English reading practice. The three items assessing academic English reading were: reading English textbooks, English tests preparation books, and academic articles in students' academic disciplines. The three items assessing non-academic English reading practice were: reading newspapers, magazines, and novels in English. The questionnaire also used a 5-point Likert anchors: $1=$ never $2=$ rarely $3=$ sometimes $4=$ always $5=$ very frequently. The reliability of the academic English reading practice and non-academic English reading practice scales were .62 and .63 respectively. The participants' English teachers checked the appropriateness of the items used in the two questionnaires before administering them. The questionnaires were written in Chinese so that the participants' English proficiency would not interfere with students' understanding of the questionnaires.

\subsubsection{The achievement in English reading test}

The achievement in English reading test was selected from a CET-Band 4 reading practice bank. Both the format of the test and the levels of the difficulty were considered appropriate, because all the participants were going to sit the CETBand 4 in the subsequent semester. The test consisted of two parts: fast reading and reading in depth. With a completion time of 10 minutes, the fast reading part aimed to examine students' abilities in skimming and scanning a long text by answering five multiple choice comprehension questions. Each correct answer in the fast reading part was scored of 2 points, with a total of 10 points for this part. With a completion time of 30 minutes, the reading in depth part was designed to test students' abilities to draw inferences from the content, finding detailed and specific answers, and summarizing the main idea of the texts by responding to 15 comprehension questions after reading three texts ( 5 questions for each text). The correct answer in the reading in depth part was also 2 point, with a total of 30 points. The maximum achievable score of the reading test was 40 . The study was carried out in the English classes in the first semester of year two and took approximately 50 minutes to complete. The participants first spent 40 minutes to complete the reading test and spent an additional 10 minutes to fill the two questionnaires. 


\section{DATA ANALYSIS}

Data analyses were conducted using SPSS 22 for both descriptive and inferential statistics. To answer the first research question, the scores of intrinsic motivation in English reading and extrinsic motivation in English reading scales were used to cluster students via a hierarchical cluster analysis. Based on the yielded cluster membership, one-way ANOVAs were applied to examine if students in different clusters with different levels of motivation in English reading differed on the amount of academic and non-academic English reading and English reading test scores. To answer the second research question, correlation analyses were conducted. To provide the answer to the last research question, a path model was constructed. The path model was able to simultaneously explicate the complex relations such as the mediation effects, at the same time it could control measurement errors (Kline, 2005). To evaluate the appropriateness of the path model, the guidelines in Kline (2005) and Jöreskog and Sörbom (2005) were followed. As the chi-square statistics is influenced by sample size, the three most commonly used fit statistics were adopted as primary indicators of model fit, namely the Tucker-Lewis Index (TLI, Tucker and Lewis, 1973), the Comparative Fit Index (CFI, Bentler, 1990), and the root mean square error of approximation (RMSEA, Browne and Cudeck, 1993). The values of TLI and CFI higher than .90, RMSEA lower than .06, can be considered as an acceptable model fit (Bentler, 1990; Browne and Cudeck, 1993).

\section{FINDINGS}

\subsection{Descriptive Statistics}

Table II displays descriptive statistics of the minimum, maximum, $M s$ and $S D s$ of the two motivation in English reading scales, two scales of the amount of out-ofclass English reading, and reading achievement scores.

Table II. Descriptive statistics.

\begin{tabular}{lllll}
\hline Variables & minimum & maximum & M & SD \\
\hline intrinsic motivation & 1.00 & 4.40 & 3.07 & 0.57 \\
extrinsic motivation & 1.00 & 4.87 & 3.54 & 0.46 \\
amount of academic reading & 1.00 & 4.33 & 2.27 & 0.81 \\
amount of non-academic reading & 1.00 & 4.33 & 1.99 & 0.70 \\
reading achievement & 6.00 & 38.00 & 21.53 & 5.79 \\
\hline
\end{tabular}




\subsection{Results of Relations between Motivation in English reading, the Amount of Out-of-class English Reading, and English Reading Achievement at the Level of Students}

For the hierarchical cluster analysis, based on the increasing values of the Euclidian distance and consultancy with the Dendrogram, a two-cluster solution was retained: one cluster has 147 students and the other has 175 students. Table III displays the distribution of the clusters and one-way ANOVAs.

Table III. Distribution of the clusters and the results of one-way ANOVAs

\begin{tabular}{|c|c|c|c|c|c|c|c|}
\hline \multirow[t]{2}{*}{ variables } & \multicolumn{2}{|c|}{$\begin{array}{l}\text { higher } \\
\text { motivation } \\
(N=147)\end{array}$} & \multicolumn{2}{|c|}{$\begin{array}{c}\text { lower } \\
\text { motivation } \\
(N=175)\end{array}$} & \multirow[t]{2}{*}{$F$} & \multirow[t]{2}{*}{$p$} & \multirow[t]{2}{*}{$\eta^{2}$} \\
\hline & $M$ & $S D$ & $M$ & $S D$ & & & \\
\hline intrinsic motivation & 3.27 & 0.30 & 2.52 & 0.41 & 326.88 & .00 & .51 \\
\hline extrinsic motivation & 3.86 & 0.29 & 3.27 & 0.39 & 236.68 & .00 & .43 \\
\hline $\begin{array}{l}\text { amount of academic } \\
\text { reading }\end{array}$ & 2.55 & 0.78 & 2.03 & 0.77 & 36.05 & .00 & .11 \\
\hline $\begin{array}{l}\text { amount of non-academic } \\
\text { reading }\end{array}$ & 2.23 & 0.71 & 1.79 & 0.63 & 34.85 & .00 & .10 \\
\hline reading achievement & 22.67 & 5.91 & 20.57 & 5.53 & 10.77 & .00 & .03 \\
\hline
\end{tabular}

One way ANOVAs showed that all the four scales, and the English reading achievement scores differed significantly between the two clusters (intrinsic motivation in English reading: $F(1,320)=$ $326.88, p<.01, \eta^{2}=.51$; extrinsic motivation in English reading: $F(1,320)=236.68, p<.01, \eta^{2}=$ .43 ; the amount of academic English reading: $F(1,320)=36.05, p<.01, \eta^{2}=.11$; the amount of non-academic English reading: $F(1,320)=34.85, p<.01, \eta^{2}=.10$; and achievement scores: $F(1$, 320) $\left.=10.77, p<.01, \eta^{2}=.03\right)$.

Cluster one students reported significantly higher on both intrinsic motivation in English reading $(M=3.27, S D=0.30)$; extrinsic motivation in English reading $(M=3.86, S D=0.29)$ than cluster two students (intrinsic: $M=2.52, S D=$ 0.41 ; extrinsic: $M=3.27, S D=0.39$ ). Thus, cluster one was referred to as higher motivation group and cluster two as lower motivation group. One-way ANOVAs further revealed that the higher motivation group significantly read more out of their English classes not only in the academic fields $(M=2.55, S D=0.78)$, but also in the non-academic fields $(M=2.23, S D=0.71)$ than the lower motivation counterparts (academic: $M=2.03, S D=0.77$; non-academic: $M=1.79, S D=$ $0.63)$. At the same time, the students with higher motivation in English reading 
$(M=22.67, S D=5.91)$ also performed significantly better in English reading test than their peers with lower motivation in English reading $(M=20.57, S D=5.53)$.

\subsection{Results of Relations between Motivation in English reading, the Amount of Out-of-class English Reading, and English Reading Achievement at the Level of Variables}

Table IV presents the results of correlation analyses to show the pairwise relations amongst variables. Table IV shows that intrinsic and extrinsic motivation in English reading scales were significantly and positively associated $(r=.56, p<$ $.01)$. In addition, intrinsic motivation scale was positively associated with both the amount of academic $(r=.33, p<.01)$ and non-academic English reading $(r=.31$, $p<.01)$, and the strength of the pairwise relations was similar. Likewise, extrinsic motivation scale had positive relation with both the amount of academic $(r=.29$, $p<.01)$ and non-academic English reading $(r=.28, p<.01)$. The strength of the correlations was slightly stronger between intrinsic motivation and the amount of reading than that between extrinsic motivation and the amount of reading.

Table IV. Results of correlation analyses.

\begin{tabular}{lcccc}
\hline variables & $\begin{array}{l}\text { extrinsic } \\
\text { motivation }\end{array}$ & $\begin{array}{l}\text { amount of } \\
\text { academic } \\
\text { reading }\end{array}$ & $\begin{array}{l}\text { amount of } \\
\text { non-academic } \\
\text { reading }\end{array}$ & $\begin{array}{l}\text { reading } \\
\text { achievement }\end{array}$ \\
\hline intrinsic motivation & $.56^{* *}$ & $.33^{* *}$ & $.31^{* *}$ & $.18^{* *}$ \\
extrinsic motivation & --- & $.29^{* *}$ & $.28^{* *}$ & $.18^{* *}$ \\
amount of academic & --- & --- & $.58^{* *}$ & $.24^{* *}$ \\
reading & & & --- & $.14^{*}$ \\
$\begin{array}{l}\text { amount of non- } \\
\text { academic reading }\end{array}$ & --- & --- & & \\
reading achievement & --- & --- & --- & -- \\
\hline
\end{tabular}

Note: ${ }^{* \prime} p<.01,{ }^{*} p<.05$.

Correlation analyses further show that all the scales of motivation and the amount of reading were significantly and positively related to achievement scores. The value of correlation between intrinsic motivation and reading achievement scores $(r=.18, p<.01)$ was the same as that between intrinsic motivation and reading achievement scores $(r=.18, p<.01)$; whereas the amount of academic 
English reading $(r=.24, p<.01)$ had stronger association with reading achievement scores than the amount of non-academic English reading did $(r=.14, p<$ $.05)$.

\subsection{Results of the Path Model}

A path model was constructed according to the correlation results and the literature. The path model included direct paths from the amount of academic and non-academic reading, intrinsic and extrinsic motivation, to reading achievement scores, direct paths from intrinsic motivation and extrinsic motivation to the amount of academic reading, and indirect paths from intrinsic and extrinsic motivation to achievement scores mediated by the amount of academic and nonacademic reading. The significant paths are visualized in Figure 1.

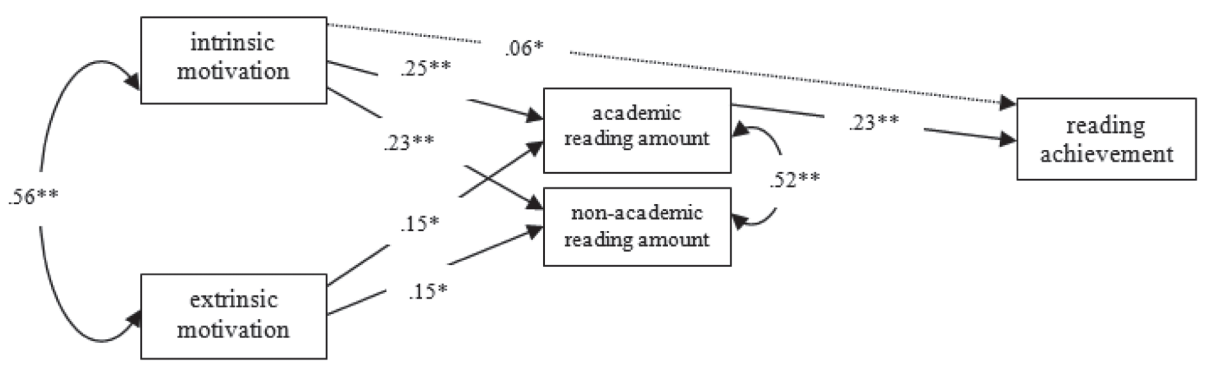

Figure 1. Visual representation of the path model.

The results of the path analysis revealed that the data fit the hypothesized model: $\chi^{2}(9)=203.89, p<.01, \mathrm{CFI}=1.00, \mathrm{TLI}=1.00, \mathrm{RMSEA}=.00$. The path from the amount of academic English reading to English reading achievement was significant $(\beta=.23, p<.01)$, whereas none of the paths from the amount of non-academic English reading $(\beta=-.04, p=.55)$, intrinsic motivation $(\beta=.07, p$ $=.31)$, and extrinsic motivation $(\beta=.09, p=.16)$ to English reading achievement reached significance. Intrinsic $(\beta=.25, p<.01)$ and extrinsic $(\beta=.15, p<.05)$ motivation had significant and positive paths to the amount of academic English reading. Similarly, intrinsic $(\beta=.23, p<.01)$ and extrinsic $(\beta=.15, p<.05)$ motivation also had significant and positive contributions to the amount of nonacademic English reading. The coefficients were comparable amongst these paths. Furthermore, the two motivation scales had positive and moderate association $(r$ $=.56, p<.01)$; so did the amount of academic and non-academic English reading $(r=.52, p<.01)$. In terms of the indirect paths, the results showed that the only 
significant indirect path was from intrinsic motivation to the achievement scores mediated by the amount of academic English reading $(\beta=.06, p<.05)$.

\section{CONCLUSIONS}

The present study examined the relations between motivation in English reading, the amount of out-of-class English reading, and achievement in English reading at the level of students and the level of variables among a cohort of Chinese ELLs at university. At the level of students, the study showed that when students reported having higher intrinsic and extrinsic motivation in English reading, they also read academic and non-academic English texts more frequently, at the same time had better achievement in English reading. At the level of variables, intrinsic and extrinsic motivation had almost equal strength of association with the amount of academic and non-academic English reading practice outside the students' English classes.

Similar to motivation in L1 reading (e.g., Wigfield and Guthrie, 1997; Wang and Guthrie, 2004) and motivation in FL reading among other groups of learners (e.g., Kim, 2011; Lin et al., 2012; Mori, 2002; Mori, 2004; Takase, 2007), Chinese university students' motivation in English reading also consisted of intrinsic and extrinsic components. The intrinsic motivation in English reading reflects Chinese students' personal interest and engagement in English reading, whereas extrinsic motivation suggests that the purposes for Chinese students to read English are to achieve some practical goals. Utility value of English reading may enable students to broaden views, obtain information, and cope with globalization. Academic value of English reading may help students fulfill some of their academic needs through, such as performing well in English tests and learning new vocabulary. The academic value seems to reflect that reading is one of the important ways to learn English in China, and the English instruction in Chinese universities predominantly relies on reading ( $\mathrm{Gu}, 2003)$. In addition, students also attach English reading with the values of social recognition from their teachers and peers.

The positive relation between intrinsic and extrinsic motivation in English reading scales suggests that Chinese ELLs who have higher intrinsic motivation in English reading also tend to have higher extrinsic motivation in English reading. This finding provides support to the Self-Determination Theory, which maintains that the dichotomy between intrinsic and extrinsic motivation does not mean that the two types of motivation cannot co-exist within a person (Ryan and Deci, 2000; Ryan and Deci, 2016).

In the path model, which simultaneously examined motivation in English reading and the amount of out-of-class English reading to English reading 
achievement, only the amount of academic English reading directly contributed to the English reading achievement, explaining around 5.29\% of variance. Intrinsic motivation indirectly predicted English reading achievement via the mediator of the amount of academic English reading, only accounting for approximately $0.36 \%$ of variance. Even though extrinsic motivation in English reading neither directly nor indirectly predicted achievement in English reading, extrinsic motivation made significant contribution to the amount of academic English reading, explaining around $2.25 \%$ of the variance.

The results of the current study have some practical implications in teaching. For Chinese university students to attain a good level of English reading comprehension, encourage students to utilize their own time to practice academic English reading seems to be important. Apart from practicing academic English reading after English classes, fostering students' intrinsic and extrinsic motivation is also essential, which might be useful to enhance Chinese students' English reading achievement.

One of the ways to cultivate students' intrinsic motivation could be to give students' autonomy to choose topics they are interested in. In English classes, teachers may ask students to bring some texts to the class and use them as sources to expand vocabulary and to learning new grammatical structures. To increase students' extrinsic motivation, English teachers of Chinese ELLs may explicitly point out the benefits and importance of English reading in different realms of students' life in order to intrigue students' interests in English reading. For instance, teachers may bring English newspapers to the classroom and ask students to learn about what is happening in the country and in the world through reading English newspapers so that they can see the practical outcomes of their English reading in their daily life.

\section{REFERENCES}

Baker, Linda, and Allan Wigfield. (1999). Dimensions of children's motivation for reading and their relations to reading activity and reading proficiency. Reading Research Quarterly, 34, 452-77.

Bentler, Peter. (1990). Comparative fit indexes in structural models. Psychological Bulletin, 107, 238-246.

Browne, Michael, and Robert Cudeck. (1993). Alternative ways of assessing model fit. In K. A. Bollen, and J. S. Long Eds., Testing Structural Equation Models (pp. 136-162). Beverly Hills, CA: Sage.

Gardner, Robert. (2001). Integrative motivation and second language acquisition. In Z. Dornyei and R. Schmidt Eds., Motivation and Second Language Acquisition (pp. 1-19). Honolulu, HI: University of Hawai'i Press. 
Gottfried, Adele. (1990). Academic intrinsic motivation in young elementary school children. Journal of Educational Psychology, 82, 525-38.

Grabe, William, and Stoller, Fredricka. (2013). Teaching and researching: Reading. Routledge.

Gu, Peter Yongqi. (2003). Fine brush and freehand: The vocabulary-learning art of two successful Chinese EFL learners. TESOL Quarterly, 37, 73-104.

Guthrie, John, and Allan Wigfield. (2000). Engagement and motivation in reading. In M. L. Kamil, P. B. Mosenthal, P. D. Pearson, and R. Barr Eds., Handbook of Reading Research, Volume 3 (pp. 403-422). Mahwah, NJ: Lawrence Erlbaum.

Guthrie, John, Laurel Hoa, Allan Wigfield, Stephen Tonks, Nicole Humenick, and Erin Littles. (2007). Reading motivation and reading comprehension growth in the later elementary years. Contemporary Educational Psychology, 32, 282-313.

Guthrie, John, Allan Wigfield, Jamie Metsala, and Kathleen Cox. (1999). Motivational and cognitive predictors of text comprehension and amount of reading. Scientific Studies of Reading, 3, 231-56.

Han, Feifei. (2012). Comprehension monitoring in English reading as a foreign language. New Zealand Studies in Applied Linguistics, 18, 36-49.

Jöreskog, Karl, and Dag Sörbom. (2005). LISREL 8.72: Structural Equation Modelling with SIMPLIS Command Language. Chicago, IL: Scientific Software International.

Kim, Kyung Ja. (2011). Reading motivation in two languages: An examination of EL2 college students in Korea. Reading and Writing: An Interdisciplinary Journal, 24, 861-81.

Kline, Rex. (2005). Principles and Practices of Structural Equation Modelling 2nd ed. New York, NY: Guilford.

Lau, Kit-ling, and David Chan. (2003). Reading use of strategy and motivation among Chinese good and poor readers in Hong Kong. Journal of Research in Reading, 26, 177-90.

Law, Yin-kum. (2009). The role of attribution beliefs, motivation and use of strategy in Chinese fifth-graders' reading comprehension. Educational Research, 51, 77-95.

Lin, Dan, Ka Ki Wong, and Catherine McBride-Chang. (2012). Reading motivation and reading comprehension in Chinese and English among Hong Kong Chinese fifth graders. Reading and Writing: An Interdisciplinary Journal, 25, 717-37.

Mori, Setsuko. (2002). Redefining motivation to read in a foreign language. Reading in a Foreign Language, 14, 91-110.

Mori, Setsuko. (2004). Significant motivational predictors of the reading frequency by EFL learners in Japan. Regional Language Centre Journal, 35, 63-81. 
Mucherah, Winnie, and Alyssa Yoder. (2008). Motivation for reading and middle school students' proficiency on standardized testing in reading. Reading Psychology, 29, 214-35.

Ryan, Richard, and Edward Deci. (2000). Intrinsic and extrinsic motivations: Classic definitions and new directions. Contemporary Educational Psychology, 25, 54-67.

Ryan, Richard, and Edward Deci. (2016). Facilitating and hindering motivation, learning, and well-being in schools: Research and observations from Self-Determination Theory. In K. Wentzel and D. Miele Eds., Handbook of Motivation at School (pp. 96-119). New York: Routledge.

Schaffner, Ellen, Ulrich Schiefele, and Hannah Ulferts. (2013). Amount of reading as a mediator of the effects of intrinsic and extrinsic reading motivation on reading comprehension. Reading Research Quarterly, 484, 369-385.

Schutte, Nicola, and John Malouff. (2007). Dimensions of reading motivation: Development of an Adult Reading Motivation Scale. Reading Psychology, 28, 469-89.

Takase, Atsuko. (2007). Japanese high school students' motivation for extensive L2 reading. Reading in a Foreign Language, 19, 1-18.

Tucker, Ledyard, and Charles Lewis.(1973). A reliability coefficient for maximum likelihood factor analysis. Psychometrika, 38, 1-10.

Vansteenkiste, Maarten, Joke Simons, Willy Lens, Kennon Sheldon, and Edward Deci. (2004). Motivating learning, proficiency, and persistence: The synergistic effects of intrinsic goal contents and autonomy-supportive contexts. Journal of Personality and Social Psychology, 87, 246-60.

Wang, Judy huei-yu, and John Guthrie. (2004). Modeling the effects of intrinsic motivation, extrinsic motivation, reading frequency, and past reading proficiency on text comprehension between U.S. and Chinese students. Reading Research Quarterly, 39, 162-86.

Wigfield, Allan. (1997a). Children's motivations for reading and reading engagement. In J. Guthrie and A. Wigfield Eds., Reading Engagement: Motivating Readers through Integrated Instruction (pp. 14-33). Newark, DE: Reading Association.

Wigfield, Allan. (1997b). Reading motivation: A domain-specific approach to motivation. Educational Psychologist, 32, 59-68.

Wigfield, Allan, and John Guthrie. (1997). Relations of children's motivation for reading to the amount and breadth of their reading. Journal of Educational Psychology, 89, 420-32. 